\title{
PUC
}

MARIA DAS GRAÇAS LINO LABRUNIE

\section{MÁQUINAS DIDATIZADAS: UMA ANÁLISE DOS USOS DAS TECNOLOGIAS DA COMUNICAÇÃO E DA INFORMAÇÃO NA ESCOLA}

\author{
Dissertação apresentada ao \\ Departamento de Educação da \\ $\mathrm{PUC} / \mathrm{RJ}$ como parte dos requisitos \\ para a obtenção do título de Mestre \\ em Educação. \\ Orientadora: Prof ${ }^{a}$. Rosália Duarte
}

\author{
DEPARTAMENTO DE EDUCAÇÃO \\ PONTIFÍCIA UNIVERSIDADE CATÓLICA DO RIO DE JANEIRO \\ RIO DE JANEIRO, MARÇO DE 2004
}


MARIA DAS GRAÇAS LINO LABRUNIE

MÁQUINAS DIDATIZADAS: UMA ANÁLISE DOS USOS DAS TECNOLOGIAS DA COMUNICAÇÃO E DA INFORMAÇÃO NA ESCOLA

Dissertação apresentada como requisito parcial para obtenção do grau de Mestre pelo Programa de Pós-graduação em Educação do Departamento de Educação do Centro de Teologia e Ciências Humanas da PUC-Rio. Aprovada pela Comissão Examinadora abaixo assinada.

Profa. Rosália Maria Duarte

Orientadora PUC-RIO

Profa. Maria Inês G. F. Marcondes de Souza

Presidente

PUC-RIO

Prof $^{\circ}$ Ernani Almeida Ferraz

UFJF

Prof ${ }^{\circ}$ PAULO FERNANDO CARNEIRO DE ANDRADE

Coordenador Setorial do Centro de Teologia

e Ciências Humanas - PUC-Rio

Rio de Janeiro, 
Todos os direitos reservados. É proibida a reprodução total ou parcial do trabalho sem autorização do autor, do orientador e da universidade.

\section{Maria das Graças Lino Labrunie}

Graduou-se em Comunicação Social pela UFRJ (Universidade Federal do Rio de Janeiro) em 1988. Possui os títulos de Especialista em Língua Inglesa (PUC-Rio - 1995) e em Informática Educativa (UERJ - 2003). Trabalha como professora de inglês no Colégio Pedro II desde 1995. Durante o Mestrado participou do grupo de pesquisa intitulado: "Filmes e Valores Morais", coordenado pela Profa. Rosália Duarte.

Ficha Catalográfica

Labrunie, Maria das Graças Lino

Máquinas didatizadas : uma análise dos usos das tecnologias da comunicação e da informação na escola / Maria das Graças Lino Labrunie ; orientadora: Rosália Duarte. - Rio de Janeiro : PUC, Departamento de Educação, 2004.

172 f. : il. ; $30 \mathrm{~cm}$

Dissertação (mestrado) - Pontifícia Universidade Católica do Rio de Janeiro, Departamento de Educação.

Inclui referências bibliográficas.

1. Educação - Teses. 2. Tecnologias. 3. Escola. 4. Cultura. 5. Computador. 6. Televisão. I. Duarte, Rosália. II. Pontifícia Universidade Católica do Rio de Janeiro. Departamento de Educação. III. Título. 
A meus pais muito queridos, Conceição e Weimar, por estarem sempre presentes em minha vida, dando força quando desanimo, carinho quando preciso e ouvidos atentos e críticos às minhas produções.

A Charles, meu companheiro e amor, por ter entrelaçado seu destino ao meu e me proporcionado a paz necessária para seguir em frente em minhas decisões.

A meus filhos, Cristiano e Mateus, que representam, para mim, a alegria, o sentido de viver, a renovação. 


\section{AGRADECIMENTOS}

Gostaria de agradecer a todas as pessoas que me abriram suas portas para a realização desta instigante viagem: os professores e funcionários do Colégio Pedro II Ana Paula, Cristina, Eliane, Ingrid, Isabel, Kaká, Lourdes, Marcelo, Maria Alice, Marisa, Patrícia, Paulo Rogério, Vanessa e Vera, sem os quais a pesquisa não teria a riqueza necessária; os professores do Colégio Santo Inácio e EDEM, Eduardo e Ronaldo por seu interesse em contribuir para esta pesquisa e possibilitarem meu olhar para uma perspectiva diferente.

A minhas colegas de pesquisa, Adriana, Camila, Cristiane, Dayse, Elaine, Ilana, Rita, Stella, pelas reflexões, diálogos fecundos, carinho e cooperação.

A meus colegas de turma, com quem pude dividir a ansiedade do caminhar.

Aos professores do Departamento de Educação da PUC-Rio, em especial Leandro Konder, que me revelaram novos horizontes no âmbito da educação, e deste modo, permitiram enriquecer as reflexões em torno do tema da pesquisa.

Aos autores que li e que me fizeram vislumbrar dimensões originais e diferentes da realidade.

A meus familiares e amigos.

Agradeço em especial a minha orientadora, Rosália Duarte, a quem admiro por sua inteligência, profundidade, meiguice, amizade e paciência, virtudes essas que foram preciosas para a elaboração e conclusão deste trabalho. 


\title{
Máquinas didatizadas: uma análise dos usos das tecnologias da comunicação e da informação na escola
}

\begin{abstract}
Resumo
A instituição escolar se defronta com o grande desafio de se transformar, pressionada pelas novas configurações sociais que surgem nos últimos tempos. Dentre estas, está a convivência das novas gerações com as tecnologias, principalmente a TV e o computador. Este estudo procura entender esse processo e faz uma análise das atividades em que a TV e o computador são usados nas aulas para compreender de que forma a escola poderá contribuir para que os alunos se tornem usuários criativos e críticos destas novas ferramentas e não meros consumidores de representações novas de velhos clichês. A partir de uma reflexão crítica sobre a cultura audiovisual e seu confronto com a cultura escolar, foram realizadas observações de aulas em que são utilizadas as tecnologias, bem como apreciações do discurso pedagógico de alguns professores de ensino fundamental ( $2^{\circ}$ segmento) de uma escola pública do Rio de Janeiro.

O resultado sugere que as atividades que são feitas com a utilização das tecnologias possibilitam enriquecer o discurso oral e impresso típicos da escola, já que introduzem imagem, movimento e interação comunicativa intra/inter escolar aos conteúdos tradicionais e que o computador tem, especificamente, o potencial de promover uma mudança de paradigma, na medida em que pressupõe diferentes modos de aprender e ensinar.

Verificou-se também que, para a maioria dos docentes entrevistados, as tecnologias de comunicação e informação não têm caráter transformador e são usadas, principalmente, como um complemento às aulas. Apesar de reconhecerem que mudanças precisam ser realizadas, os docentes não parecem crer que elas virão através das tecnologias. Eles acreditam que as máquinas, ao entrarem na escola, devem ser didatizadas para se adequarem à cultura escolar.
\end{abstract}

Palavras-chave: tecnologias, escola, cultura, computador, TV, educação 


\title{
Didactized Machines: an analysis of the uses of communication and information technologies in school
}

\begin{abstract}
The school institution is confronted with the great challenge of making changes, pressed by the new social configurations that appear in the beginning of the century. Among these, it is the coexistence of the new generations with the technologies, mainly TV and the computer.

This study tries to understand this process and makes an analysis of the activities where the TV and the computer are used in the classes, in order to understand how the school can contribute that the students become creative and critical users of these new tools and not mere consumers of new representations of old clichés. Starting from a critical reflection on the audiovisual culture and its confrontation with the school culture, observations of classes (where the technologies are used) were accomplished, as well as appreciations of the pedagogic speech of some teachers of fundamental teaching (2o segment) of a public school of Rio de Janeiro.

The result suggests that the activities that are done with the use of the technologies make it possible to enrich the oral and printed work typical of the school, since they introduce image, movement and intra/inter communicative interaction to the traditional contents. The computer specifically, has the potential of promoting a paradigm change, as it presupposes changes in the manners of learning and teaching.

It was also verified that, for most of the interviewed teachers, the communication and information technologies don't have potential for transformations and they are used, mainly, as a complement to the classes. In spite of the fact that the teachers recognize that changes need to be accomplished, they don't seem to believe that they will happen through the technologies. They believe that the machines, when entering the school, should be didactized to adapt to the school culture.
\end{abstract}

Key-words: technologies, school, culture, computer, TV, education 


\section{SUMÁRIO}

1. Prólogo

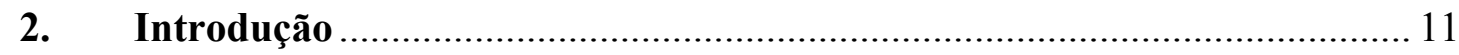

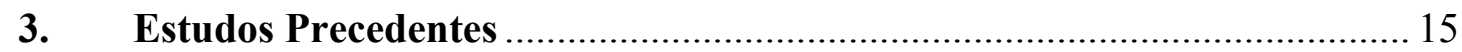

3.1 As tecnologias e a cultura audiovisual ............................................... 16

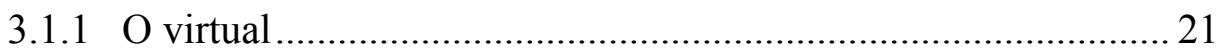

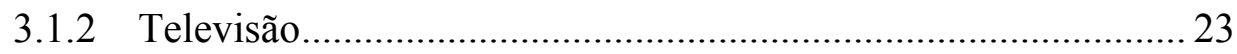

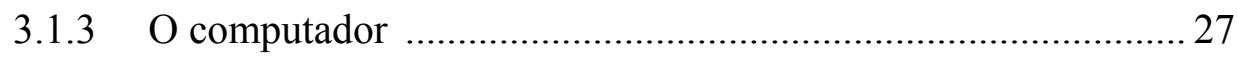

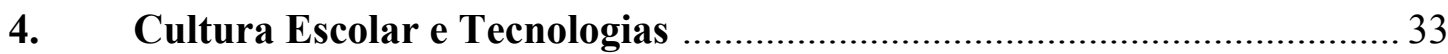

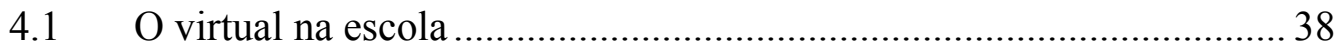

4.2 Duas dimensões de virtualidade ........................................................ 42

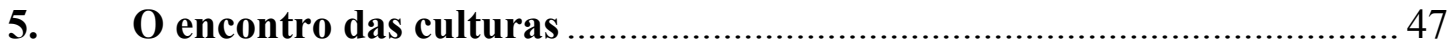

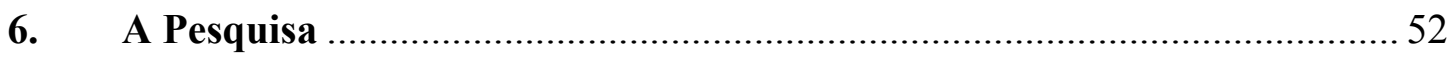

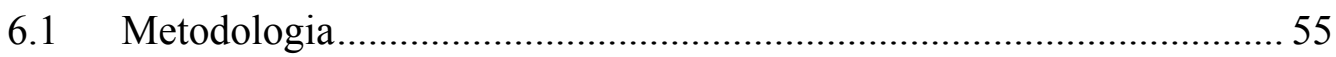

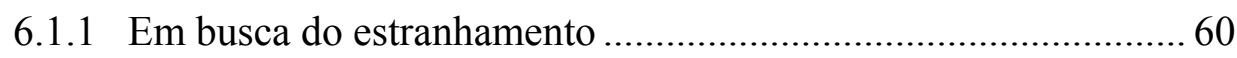

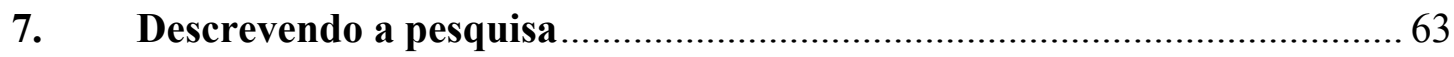

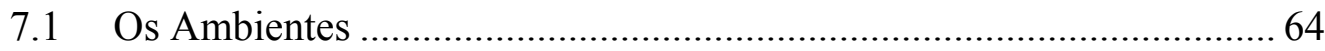

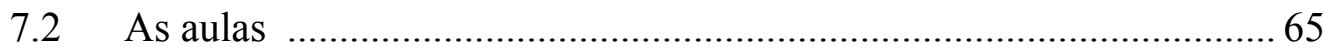

8. Em busca de uma tipologia de usos da mídia na escola ………………...... 78

8.1 Objetivos dos professores …………………………………………..... 81

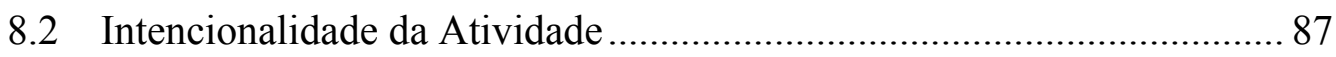

8.3 Formatos disciplinares e usos das tecnologias ………………………..... 93

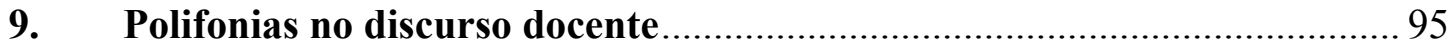

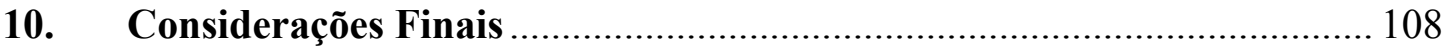

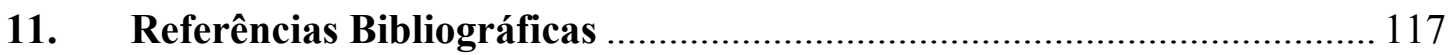

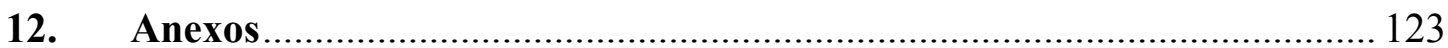




\section{Prólogo}

Acuado, Neo sobe as escadas de um prédio velho e corre ao longo do corredor procurando o apartamento de onde tocava o telefone. Naquele momento, aquela era sua salvação: atender o telefone para sair do mundo virtual, mundo bonito onde o ser humano era controlado por máquinas e entrar no mundo real, árido, frio, mas onde o homem tomava seu destino em suas mãos.

Ao entrar no apartamento onde tocava o telefone, Neo encontra um dos agentes com a arma apontada para ele. $O$ agente atira. Neo, a princípio tem dúvidas se deve acreditar que morreu ou não, pois ainda estava no mundo virtual. Mas os tiros se seguem e a dúvida se acaba. Neo tomba morto no chão. No mundo real, a nave está sendo atacada pelas máquinas dominadoras e os companheiros de Neo, ao perceberem sua morte, ficam estarrecidos. Afinal, ele não era o Escolhido? O Oráculo errou? Mas Trinity não deixou de acreditar. Vira-se para o corpo de Neo, plugado à máquina e diz: -"o Oráculo disse que eu me apaixonaria pelo Escolhido e eu estou apaixonada por você, então, você é o Escolhido e não morreu". Beija-o suavemente. Neo, como que por milagre, ressuscita na vida real e na virtual. Levanta-se, olha para os agentes, personificações da máquina e, mais forte do que nunca, consegue ver códigos no lugar das representações do mundo virtual. A partir daí, a força de sua mente é invencivel. Nenhuma máquina poderá enganá-lo. Ele vê os códigos, os bastidores da linguagem do computador que havia criado aquele mundo virtual: a Matrix. Os agentes atiram contra ele, mas sua mente compreende que são apenas tiros virtuais, e as balas param no ar. Um agente se joga contra ele, numa luta rápida, mas Neo calmamente o imobiliza. Finalmente, voando contra o agente, Neo se joga por dentro do seu corpo e ultrapassa-o como um fantasma. Ele conseguiu perceber que, por trás dos agentes da máquina, só havia códigos e a realidade virtual era apenas uma aparência de real, que só serviria para enganá-los e manter o controle das máquinas sobre os homens.

(descrição livre da cena final do filme Matrix, dirigido pelos irmãos Warchowsky) 
Esta cena de filme me tocou muito, pois mostra a força que uma pessoa adquire quando consegue ver o mundo, não mais pela maneira como the apresenta o sistema, mas pela maneira como ela, com a mente liberta, enxerga as coisas como são realmente constituídas. Aqui fala-se de fé, de lucidez, de racionalidade versus emoção, de homem versus máquina. Fala-se também de um mundo onde os limites entre o real e o virtual são muito tênues, onde as máquinas expandem cada vez mais seus âmbitos, onde a espetacularização nos impede de ver para além das aparências, enfim, um mundo chamado pós-moderno. E, a meu ver, como educadora que sou, a educação deveria exatamente fortalecer as novas gerações, para que elas possam ver os códigos pelos quais o mundo é composto.

O Mestrado teve para mim uma função parecida: o gradativo desvendar, através de observação e registro, dos códigos que compõem os fenômenos que me propus a pesquisar. Lendo muito, meditando, dialogando com diversos autores e professores, senti-me fortalecer mental, intuitiva e analiticamente. Deste modo, assim como ocorreu com Neo, os códigos que compõem os fatos pesquisados puderam ser compreendidos melhor e de forma mais lúcida. Obviamente que há ainda muito a aprender. Mas não seria este mesmo o papel do pesquisador? Contribuir com seu ponto de vista e seus estudos na revelação de um pedaço da realidade? Encaixar peças no quebra-cabeças do conhecimento, bordar pelo menos um ponto no grande risco do bordado do conhecimento?

Seria uma ilusão achar que se poderia esgotar toda a realidade de qualquer assunto, até porque ele não se esgota. A verdade está sempre sendo questionada e superada por uma nova verdade. Então, o que nos resta? Ficar feliz pela mente fortalecida, pelo novo olhar sobre o fenômeno estudado. E acreditar que sempre se pode fazer melhor ... 